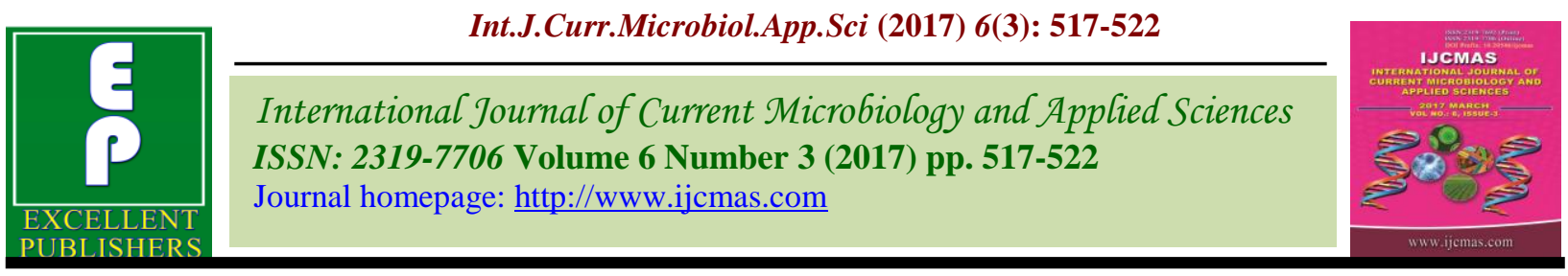

Original Research Article

https://doi.org/10.20546/ijcmas.2017.603.060

\title{
Critical Soil Water Potential and Seed Hydration Value for Germination of Soybean Varieties under Different Soil Types
}

\author{
Mahesh Jajoria $^{1}$, V.D. Patil ${ }^{1}$, R. Verma ${ }^{2}$, Indu Bala Sethi ${ }^{3}$ and H.K. Kausadikar ${ }^{1}$ \\ ${ }^{1}$ Vasantrao Naik Marathwada Krishi Vidyapeeth, Parbhani, Maharashtra- 431402, India \\ ${ }^{2}$ Sri Karan Narendra Agriculture University, Jobner, Jaipur, Rajasthan- 303329, India \\ ${ }^{3}$ G.B. Pant University of Agriculture and Technology, Pantnagar, Uttaranchal-263145, India \\ *Corresponding author
}

\section{A B S T R A C T}

\begin{tabular}{|l|}
\hline Ke y w or d s \\
$\begin{array}{l}\text { Soybean, Soil water } \\
\text { potential, Seed } \\
\text { hydration value, } \\
\text { Seed germination } \\
\text { rate. }\end{array}$ \\
\hline Article Info \\
\hline $\begin{array}{l}\text { Accepted: } \\
10 \text { February } 2017 \\
\text { Available Online: } \\
10 \text { March } 2017\end{array}$ \\
\hline \hline
\end{tabular}

A pot culture laboratory experiment was conducted during 2014-15 at Department of Soil Science and Agricultural Chemistry, Vasantrao Naik Marathwada Krishi Vidyapeeth, Parbhani using six different soybean cultivars to study the critical soil water potential and seed hydration value for germination of soybean varieties under different soil types. The experiment was laid out on clayey, loamy and sandy soil with six soybean cultivars as treatments and replicated thrice in randomized block design. The six soybean cultivars viz. JS-335, MAUS-71, MAUS-158, MAUS-162, MAUS-504 and MAUS-609 were used at two moisture levels at 50 per cent and 100 per cent field capacity. The results indicated that parameters like seed hydration value and seed germination rate were significantly influenced due to different soil moisture levels for different cultivars under study. Amongst six cultivars, MAUS-504 was found better for rainfed areas because of its lowest seed hydration value and was minimum critical soil moisture level for germination. The cultivars, JS-335 and MAUS-71 showed maximum seed hydration value and reduction in germination to a great extend under critical moisture level and showed optimum germination (90 to 95 per cent) under sufficient moisture level (100 per cent field capacity) condition. Under limiting moisture condition, MAUS-504 and MAUS-158 cultivars germinated well while JS-335 and MAUS-71 cultivars resulted in to poor germination.

\section{Introduction}

In recent year farmers are facing serious problem of soybean seed germination. It is not clear that whether low germination is due to genetical make up or soil moisture content or otherwise any other unknown reason. It is well known fact that moisture imbibition by seed is a pre-requisite for germination. For almost all crops, moisture is needed at the time of germination, early seedling and later growth stages. Seeds, however require an optimal range of moisture beyond which

either they fail to germinate or the germination is poor. The rate of seed germination is affected by the percentage of soil moisture present in the germination medium. The occurrence and the rate of germination are considerably influenced by soil moisture matric potential and hydraulic conductivity. The seeds of crops failed to germinate at or below the wilting coefficient (Collis-George and Hector, 1966). Hydration of cereals and legumes has been studied to 
understand the impact of extrinsic and intrinsic factors on water uptake (Hegarty and Scottish Horticultural Research Institute, 2012. In the sense of crop quality and productivity, the numerous studies that are carried out in legumes and in plant physiology, to understand water uptake for germination of seed of crops. The emergence of seed is essential to achieve high yield and have good quality and quantity in annual crops (Sadeghi et al., 2011).

The different soils vary in how much water they can hold and how tightly they hold as the soil dries. Seed germination and plant growth is influenced by how tightly the water is being held and not by how much total water a soil contains. This means measuring how much moisture a soil contains does not tell us enough to predict whether a seed will germinate or not. From the seeds perspective, it is how tightly the water is being held by the soil that matters. It is a critical soil water control that decides the germination of seed. The "critical soil water content" is the water amount of soil below which a significant decrease of water extraction by plant as well as the decrease of yield can be observed (Bielorai, 1973). Doneen and Doneen and MacGillwray (1943) found that the germination of crop seeds in sandy soil would depend on its water content. In the present investigation, an attempt has been made to evaluate the critical soil moisture potential and seed hydration for germination of various cultivars of soybean in different soil types.

\section{Materials and Methods}

A laboratory experiment was conducted during 2014-15 at Department of Soil science and Agricultural Chemistry, Vasantrao Naik Marathwada Krishi Vidyapeeth, Parbhani using six different soybean cultivars to study the critical soil water potential and seed hydration value for germination of soybean varieties under different soil types. The pot culture experiment was laid out on clayey, loamy and sandy soil with six soybean cultivars as treatments and replicated thrice in randomized block design. The six soybean cultivars viz. JS-335, MAUS-71, MAUS-158, MAUS-162, MAUS-504 and MAUS-609 were used at two moisture levels at 50 per cent and 100 per cent field capacity. The present investigation was conducted using three soil types viz. clayey, loamy and sandy soils having $\mathrm{pH} 7.7,8.58$ and 7.9, field capacity $36.0,24.33$ and 15.40 per cent, respectively. The details about soil properties of experimental soils and methods were given in table 1. Six soybean varieties were evaluated for their germination in different soil types and soil moisture levels. Twenty healthy seeds of each of the six cultivars of soybean were placed in petri dishes containing $200 \mathrm{gm}$ of the soil at a depth of 10 $\mathrm{mm}$ at $28^{\circ} \pm 1^{\circ} \mathrm{C}$ (Mali et al., 1978). The experiment was replicated thrice. The germination was defined when $2 \mathrm{~mm}$ long radical sprouted from the seed coat. The time of germination was considered by recording germination percentage upto 96 hours. The data on germination percentage were analysed statically (Panse and Sukhatme, 1965).

\section{Results and Discussion}

The data presented in given table 2 and 3 indicate the variation of seed hydration value of the different varieties of soybean under different soil types. When the seed attains that first critical hydration level, germination will occur. These observations suggest that there was a specific seed hydration level for each cultivar below which germination would not occur. The hydration level is governed by the internal water potential of the seed as well as external soil water potential. As the seed imbibes water during the early stages of imbibition, its water potential increases and during the later stages some internal 
metabolic modification may occur as suggested by Hadas and stibbe (1973) for corn and cotton seed.

The clayey soil at 50 per cent field capacity the results (Table 2) indicated that average seed hydration of the different soybean varieties varied due to availability of soil moisture at 50 per cent field capacity. There was a specific seed hydration level for each variety below which germination would not occur at 50 per cent field capacity.

The seeds of MAUS-162 and MAUS-504 required similar time (up to $76 \mathrm{hrs}$.) for germination at 50 per cent field capacity even though the average seed hydration value was different as $0.145 \mathrm{~g}$ and $0.125 \mathrm{~g}$ respectively. This may be due to the more seed surface area of MAUS-162 than MAUS-504. The similar findings are reported by Mali et al., (1978).
Loamy soil at 50 per cent field capacity the results indicated the significant variation in imbibition of water by different soybean cultivars. In loamy soil at 50 per cent field capacity, JS-335 absorbed maximum water (0.161 g. per seed) followed by MAUS-71. Further, the seeds of MAUS-71 and MAUS162 germinated at almost same seed hydration value but there is notable variation in time required from 44 to $36 \mathrm{hrs}$, respectively. This can be ascribed to more time required to attain the critical hydration due to lower value of external water potential at the seed surface which affect the rate of water uptake by seed (Hadas and Russo, 1974).

In sandy soil at $50 \%$ field capacity the data presented in table 2 indicated the significant variation in absorption of water by seed of soybean as a function of time. Amongst six cultivars, lowest moisture was absorbed by MAUS-504.

Table.1 Mechanical and chemical composition of experimental soil

\begin{tabular}{|c|c|c|c|c|c|c|}
\hline \multirow{2}{*}{$\begin{array}{c}\text { S. } \\
\text { No. }\end{array}$} & \multirow{2}{*}{ Particulars } & \multirow{2}{*}{ Unit } & \multicolumn{3}{|c|}{ Soil types } & \multirow[t]{2}{*}{ Method } \\
\hline & & & Clay & Loamy & Sandy & \\
\hline 1. & Coarse sand & Per cent & 11.5 & 14.20 & 19.50 & \multirow{4}{*}{$\begin{array}{l}\text { International pipette method, } \\
\text { (Piper, 1966) }\end{array}$} \\
\hline 2. & Fine sand & Per cent & 9.9 & 50.00 & 49.60 & \\
\hline 3. & Silt & Per cent & 14.5 & 24.10 & 22.50 & \\
\hline 4. & Clay & Per cent & 60.2 & 10.90 & 7.40 & \\
\hline 5. & $\mathrm{pH}$ & & 7.7 & 8.58 & 7.9 & $\begin{array}{l}\text { Suspension ratio of 1:2.5 of soil } \\
\text { water (Jackson, 1973) }\end{array}$ \\
\hline 6. & $\mathrm{EC}$ & $\mathrm{dSm}^{-1}$ & 0.06 & 0.16 & 0.25 & $\begin{array}{l}\text { 1:2.5 soil water ratio (Jackson, } \\
1973 \text { ). }\end{array}$ \\
\hline 7. & $\begin{array}{l}\text { Organic } \\
\text { carbon }\end{array}$ & $\mathrm{g} \mathrm{kg}^{-1}$ & 3.75 & 1.50 & 1.65 & $\begin{array}{l}\text { Walkley and Black's rapid } \\
\text { titration method (Piper, 1966) }\end{array}$ \\
\hline 8. & $\begin{array}{l}\text { Calcium } \\
\text { carbonate }\end{array}$ & $\mathrm{g} \mathrm{kg}^{-1}$ & 80.0 & 34.0 & 32.0 & $\begin{array}{l}\text { Rapid titration method (Piper, } \\
\text { 1966). }\end{array}$ \\
\hline 9. & CEC & $\begin{array}{l}\text { Cmol } \\
(\mathrm{p}+) \mathrm{kg}^{-}\end{array}$ & 52.14 & 12.76 & 5.72 & $\begin{array}{l}\text { Ammonium acetate method } \\
\text { (Jackson, 1973) }\end{array}$ \\
\hline 10. & $\begin{array}{l}\text { Field } \\
\text { capacity }\end{array}$ & Per cent & 36.0 & 24.33 & 15.40 & $\begin{array}{l}\text { Method No. 30, USDA Hand } \\
\text { Book No. } 60 \text { (Richards, 1968) }\end{array}$ \\
\hline
\end{tabular}


Table. 2 Critical soil water potential and seed hydration for germination of cultivars of grain soybean at $50 \%$ field capacity

\begin{tabular}{|l|c|c|c|c|c|c|c|}
\hline \multirow{2}{*}{$\begin{array}{l}\text { Sr } \\
\text { No. }\end{array}$} & \multirow{2}{*}{ Cultivars } & \multicolumn{2}{|c|}{ Clayey } & \multicolumn{2}{c|}{ Loamy } & \multicolumn{2}{c|}{ Sandy } \\
\cline { 3 - 8 } & $\begin{array}{c}\text { Time of } \\
\text { germinat } \\
\text { ion } \\
\text { (hours) }\end{array}$ & $\begin{array}{c}\text { Seed } \\
\text { hydratio } \\
\text { n value } \\
\text { (gm) }\end{array}$ & $\begin{array}{c}\text { Time of } \\
\text { germinatio } \\
\text { n (hours) }\end{array}$ & $\begin{array}{c}\text { Seed } \\
\text { hydratio } \\
\text { n value } \\
\text { (gm) }\end{array}$ & $\begin{array}{c}\text { Time of } \\
\text { germinatio } \\
\text { n (hours) }\end{array}$ & $\begin{array}{c}\text { Seed } \\
\text { hydratio } \\
\text { n value } \\
\text { (gm) }\end{array}$ \\
\hline 1. & JS-335 & 72 & 0.110 & 48 & 0.161 & 44 & 0.163 \\
\hline 2. & MAUS-71 & 56 & 0.118 & 44 & 0.146 & 40 & 0.149 \\
\hline 3. & $\begin{array}{c}\text { MAUS- } \\
158\end{array}$ & 56 & 0.114 & 40 & 0.125 & 44 & 0.133 \\
\hline 4. & $\begin{array}{c}\text { MAUS- } \\
162\end{array}$ & 76 & 0.145 & 36 & 0.140 & 48 & 0.134 \\
\hline 5. & $\begin{array}{c}\text { MAUS- } \\
504\end{array}$ & 76 & 0.125 & 64 & 0.121 & 60 & 0.120 \\
\hline 6. & $\begin{array}{c}\text { MAUS- } \\
609\end{array}$ & 80 & 0.165 & 48 & 0.136 & 60 & 0.148 \\
\hline
\end{tabular}

Table.3 Critical soil water potential and seed hydration for germination of cultivars of grain soybean at 100 per cent field capacity

\begin{tabular}{|l|c|c|c|c|c|c|c|}
\hline \multirow{2}{*}{$\begin{array}{l}\text { Sr } \\
\text { No. }\end{array}$} & \multirow{2}{*}{ Cultivars } & \multicolumn{2}{|c|}{ Clayey } & \multicolumn{2}{c|}{ Loamy } & \multicolumn{2}{c|}{ Sandy } \\
\cline { 3 - 8 } & & $\begin{array}{c}\text { Time of } \\
\text { germinat } \\
\text { ion } \\
\text { (hours) }\end{array}$ & $\begin{array}{c}\text { Seed } \\
\text { hydratio } \\
\text { n value } \\
\text { (gm.) }\end{array}$ & $\begin{array}{c}\text { Time of } \\
\text { germinatio } \\
\text { n (hours) }\end{array}$ & $\begin{array}{c}\text { Seed } \\
\text { hydratio } \\
\text { n value } \\
\text { (gm.) }\end{array}$ & $\begin{array}{c}\text { Time of } \\
\text { germinatio } \\
\text { n (hours) }\end{array}$ & $\begin{array}{c}\text { Seed } \\
\text { hydratio } \\
\text { n value } \\
\text { (gm.) }\end{array}$ \\
\hline 1. & JS-335 & 36 & 0.122 & 20 & 0.156 & 56 & 0.143 \\
\hline 2. & MAUS-71 & 36 & 0.170 & 36 & 0.142 & 44 & 0.140 \\
\hline 3. & $\begin{array}{c}\text { MAUS- } \\
158\end{array}$ & 40 & 0.150 & 44 & 0.150 & 48 & 0.132 \\
\hline 4. & $\begin{array}{c}\text { MAUS- } \\
162\end{array}$ & 32 & 0.185 & 28 & 0.159 & 52 & 0.149 \\
\hline 5. & $\begin{array}{c}\text { MAUS- } \\
504\end{array}$ & 40 & 0.135 & 36 & 0.122 & 60 & 0.099 \\
\hline 6. & $\begin{array}{c}\text { MAUS- } \\
609\end{array}$ & 32 & 0.120 & 36 & 0.178 & 52 & 0.162 \\
\hline
\end{tabular}

In these the cultivars maximum moisture was absorbed by JS-335. The maximum seed hydration value is $0.163 \mathrm{~g}$. in JS-335 and minimum seed hydration value is $0.120 \mathrm{~g}$. in MAUS-504. This can be ascribed to a function of each species to attain a specific moisture content for germination (Hunter and Erickson, 1952).
The variation of seed hydration value of different soybean varieties in clay soil at 100 per cent field capacity (Table 3) showed marked variation. The cultivars JS-335 and MAUS-609 recorded 0.122 and $0.120 \mathrm{~g}$ seed hydration. Whereas, MAUS-162 had highest seed hydration $(0.185 \mathrm{~g}$ per seed) followed by MAUS-71, MAUS-158 and MAUS-504. This 
showed that MAUS-162 soybean variety absorbed maximum water which also reflected in to improved germination. Mali et al., (1978) and Sadeghi et al., (2011) evaluated sorghum and soybean respectively for germination and recorded that seed osmopriming had positive influence on seed germination and vigour of seedling. The loamy soils under soil moisture of 100 per cent field capacity, it was observed that, soybean cultivars viz. showed sequence as MAUS-609> MAUS-162>JS-335>MAUS158> MAUS-71 >MAUS-504. This variation was occurred as every soybean cultivar has specific seed hydration value below which seeds cannot germinate. The similar observations were recorded by Mali et al., (1978).

The data (Table 3) on dry seed weight and water imbibed by soybean seed revealed that different seed hydration values of different soybean cultivars in sandy soil at 100 per cent field capacity were noted. The soybean varieties MAUS-609 showed maximum seed hydration value (0.162 g.) and MAUS-504 shows minimum seed hydration value $(0.099$ g.). This may be due to hydric, mesic and xeric habitat of seeds. Stiles (1948) reported the uptake of water by different seeds of corn, cotton and beans differ in the total amount and its rate of water absorption. Seeds apparently posses degree of hydric, mesic and xeric adoptions in germination and that varietal differences appear in water absorbing capacity of seed. The result represented in this investigation supports the findings of Stiles, 1948.

It can be concluded that amongst all cultivars MAUS-504 found better for rainfed / dry land areas because the variety MAUS-504 had lowest seed hydration value and require minimum critical soil moisture level for germination. JS-335 and MAUS-71 showed maximum seed hydration value and reduction in germination to a great extend under critical moisture level. Amongst the clay, loam and sandy soil loam soil found better in supplying the soil moisture for seed germination.

\section{References}

Bielorai, H. 1973. Prediction of irrigation needs, in: Yaron, B., Danfos, E. and Vaadia, Y. eds), Arid zone irrigation, Springer, Berlin, 359-368.

Collis-George, N. and Hactor, J.B. 1966. Germination of seeds on influenced by matric potential and by area of contact between seed soil water, Aust. J. Soil Res., 4: 145-164.

Doneen, L.D. and J.H. MacGillivray (1943. Germination (emergence) of vegetable seeds as affected by different soil moisture conditions. Plant Physiol., 18: 520-524.

Doneen, L.D. and MacCillivery. J.H. 1943. Germination of vegetables seed as affected by different soil moisture conditions, Plant Physiol., 18: 524-529.

Hadas, A. and Russo. 1974. Water uptake by seeds as affected by water stress, capillary conductivity and seed soil water contact. I. Experimental study, Agron. J., 66: 643-647.

Hadas, A. and Stibbe, E. 1973. An analysis of soil water movement towards seedling prior to emergence, physical aspects of soil water and salts in ecosystems, Ecological studies, 4: 97-106.

Hegarty, T.W., and Scottish Horticultural Research Institute, I., Dundee. 2012. The physiology of seed hydration and dehydration, and the relation between water stress and the control of germination: a review. Plant, Cell Environ., 1(2): 101-119.

Hunter, J.R. and Erickson, A.E. 1952. Relation of seed germination to soil moisture tension, Agron. J., 44: 107109. 
Jackson, M.L. 1973. Soil Chemical Analysis. Prentice Hall of India Private Ltd., New Delhi. Pp. 498.

Mali C.V., Varade S.B., Musande V.G and Chalwade P.B. 1978. Critical soil water potential and seed hydration for germination of grain sorghum. Curr. Sci., 47: 587-588.

Panse, V.G. and Sukhatme, P.V. 1965. Statistical method for agricultural workers. ICAR, New Delhi.

Piper, C.S. 1966. Soil and Plant Analysis. Hans Publishers, Bombay, pp 368.

Richards, L.A. 1968. Diagnosis and improvement of saline and alkali soils.USDA. Hand Book 60. Oxford and IBH Publishing Co., New Delhi.
Sadeghi, H., Khazaei, F., Yari, L. and Sheidaei, S. 2011. Effect of seed osmopriming on seed germination behavior and vigor of soybean (Glycine $\max$ L.. ARPN J. Agri. Biol. Sci., vol. 6(1): 39-43.

Sadeghi, H., Khazaei, F., Yari, L. and Sheidaei, S. 2011. Effect of seed osmopriming on seed germination behavior and vigor of soybean (Glycine $\max$ L. ARPN J. Agri. Biol. Sci., vol. 6(1): 39-43.

Stiles, J.E. 1948. Relation of water to the germination of corn and cotton seeds. Plant Physiol., 23: 201-222.

\section{How to cite this article:}

Mahesh Jajoria, V.D. Patil, R. Verma, Indu Bala Sethi and Kausadikar, H.K. 2017. Critical Soil Water Potential and Seed Hydration Value for Germination of Soybean Varieties under Different Soil Types. Int.J.Curr.Microbiol.App.Sci. 6(3): 517-522.

doi: https://doi.org/10.20546/ijcmas.2017.603.060 